\title{
Moderating Effect of Corporate Governance Structure between Corporate Social Responsibility and Performance
}

\author{
Keyong-Hwa Yeon* \\ Department of Business Administration, Cheongju University, 298 Daeseong-ro Cheongwon-gu Cheongju-si \\ Chungcheongbuk-do, 28503, Republic of Korea; yknwao@nate.com
}

\begin{abstract}
Objectives: To empirically analyze the moderating effect of corporate governance structure between CSR and the corporate performance. Methods/Statistical Analysis: To figure out if the corporate governance structure affects the corporate performance through CSR, this paper set the governance structure propriety factor as independent variable, the social responsibility as mediating variable, and the corporate performance as dependent variable. And Moderator regression analysis was conducted to verify the moderating effect of the governance structure between CSR and the corporate performance. Analysis was carried out in four steps regression. Findings: The result of empirical analysis is as follows: First, CSR has a positive effect on the performance; second, the governance structure has a moderating effect between CSR and the performance. In the process to implement CSR activity, agency costs would be incurred from a conflict between shareholders and the board. So considering that the effect CSR has on the performance is subject to the governance structure, sound governance structure may improve the corporate performance. This paper among other studies on CSR has significance in that it analyzed the moderating effect of corporate governance structure between CSR and the corporate performance for the first time. Above all, the inducements to implement CSR activities voluntarily and consistently were found. The significant result of this study is also practically meaningful and able to present a direction for policy making of the government on the corporate social responsibility. Improvements/Applications: The tasks to be done in the future include a relevant study consists of a considerable number of samples and time series data covering long period.
\end{abstract}

Keywords: CSR (Corporate Social Responsibility), Corporate Governance Structure, Moderating Effect, The Corporate Performance (Return on Assets)

\section{Introduction}

As the influence from corporations to the society is increasing, concerns about non-financial outcomes have been increased and the necessity of CSR activity has been growing. Thus, mature awareness of consumers, investors, and the staff has come to expect corporate activities including not only the product, price, quality, but also environmental protection, human right protection, and social charity activities in different fields.
Recently the awareness on CSR activity has widely spread with global corporations as the center. The awareness on CSR activity has also spread in domestic corporations involving charity, volunteer activity, law-abidingness, human right protection, and local community contribution, which increases importance. However, it is not easy for the corporation to maximize the profit, which is the essential objective of a corporation, while it sticks to CSR activity at the same time. The reasons for that include that the concept of CSR is

${ }^{*}$ Author for correspondence 
ambiguous and there are disagreements on CSR among shareholders. Recently, however, the effect of CSR has received much attention, and considering that implementation of CSR activities can improve corporate long-term competitiveness, corporations have put plenty of money in CSR activity ${ }^{1}$.

Thus, it was considered that CSR activity is a voluntary corporate activity in the past but it is considered as a crucial responsibility for long-term survival at present. Furthermore, in addition to the change in customers' awareness, the rapidly changing global economic environments require not only economic outcomes, but also environmental and social responsibility. Under this condition, precedent studies on CSR suggested that the corporation covering the needs and concerns of interested parties outside performed better than shareholder driven corporation and that CSR activity had a positive effect in administrative profit ${ }^{2-4}$. Therefore, if a corporation increased the corporate performance with CSR activity, CSR would be an administrative strategy. However, because the degree and range of the CSR activity is determined by executives, the effect CSR has on the corporate performance may vary according to the ownership and governance structure including the board of directors. In other words, if the governance structure and the fulfillment of responsibility were superb, that would positively affect the financial soundness, the mitigation of asymmetric information, and financial performance.

The study set an objective to empirically analyze the moderating effect of corporate governance structure between CSR and the corporate performance.

\subsection{Social Responsibility}

Bowen who firstly referred to the term, Social Responsibility, defined SR as "the obligations of businessmen to pursue those policies, to make those decisions, or to follow those lines of action which are desirable in terms of the objectives and values of our society ${ }^{5}$. Reference ${ }^{6}$ defined SR as "the normative system that ought to meet the needs and expectations of interested parties and the public by solving social and economic problem caused by corporate activities".

To sum the definitions of CSR suggested by researchers, it is to meet the needs and expectations of interested parties and secure the society in harmony with the fulfillment of overall responsibility for the society to which the corporation belongs and with efforts to solve social and economic problems beyond the objective to maximize the profit.
According to ${ }^{\underline{z}}$ the reason why the relationship between corporations and society is significant is as follows ${ }^{\mathrm{z}}$. First, the influence from a corporation to the society is huge as the corporation is getting bigger. Second, concerns about corporate non-administrative aspect and social aspect have begun to increase. Third, conflicts related to pollution and environmental problem resulted from corporate activities have frequently occurred. Fourth, consumer and citizen movements have actively proceeded. Fifth, local problems develop into social problems as IT technology and the mass media develop. For these reasons, the relationship between the corporation and the society has become significant, and the corporation has come to fulfill the social responsibility in all areas of administrative activities for a number of interested parties.

For these reasons, the corporation, in accordance with social responsibility, needs to make the profit for shareholders, improve the work environment, and moreover, implement social contribution activities in terms of environmental problem, human right problem, and fundraising. These CSR activities are associated with the consistent survival and growth of the corporation. After all, the corporation needs to pursue administration system that reflects understandings and needs of all the interested parties surrounding the corporation as well as shareholders.

\subsection{CSR and Corporate Performance}

There are two opposed viewpoints to see the potential relationship between CSR and financial performance. The first viewpoint with which one assumes that executives would abuse the corporate resources for private objective or other objectives like the viewpoint to agency costs, which ultimately results in sacrifice in the value of shareholders because of the undesirable deed of executives is a negative viewpoint ${ }^{\stackrel{8}{ }}$. They assert that in order to fulfill CSR, additional production cost would occur and considering CSR, the corporation would withdraw a profitable business or strategy, which ultimately causes the decrease in economic performance ${ }^{3}$. Second viewpoint is based on the assumption that because the corporation would have problems of additional expense and increased risks due to the conflict with employees, customers, providers, and local communities, it should make an effort to maximize the wealth of interested parties and CSR activity, which will ultimately increase the value of the corporation by making the conflict between the corporation and 
interested parties decreased. In other words, it is an argument that considering the aspect of interested parties, by making multidimensional corporate social outcomes according to the characteristics of each interested party, financial performance can be improved ${ }^{9,10}$. As for precedent studies regarding those opposed viewpoints, there were some studies that show the positive effect between CSR and the corporate performance ${ }^{4,7,11,12}$; other studies that show the negative effect between CSR and the performance ${ }^{3,13}$. There were the other studies that argue that there is no connection ${ }^{14-16}$.

In precedent studies, the relationship between CSR and the corporate performance didn't show coherent results according to different indices and financial performance index selected as the measurement value of sample, methodology, the concept of CSR. However, this study set the following hypothesis based on the precedent studies that argue CSR has a positive effect on the performance.

Hypothesis 1: CSR would have a significant positive effect on the corporate performance.

\subsection{Moderating Effect of Governance Structure}

As a way to improve the performance, one would rely on the autonomous power of executives in the governance structure, or he would monitor and control the CSR activity by interested parties and urge the executives with efficient decision making. In modern corporations that separate ownership and management, the most important role of the board is the role to monitor to maximize the profit of shareholders, efficiently controlling opportunistic behavior of executives resulted from the difference of interests between the administrator and owner $\frac{17,18}{}$. After examining whether CSR activity would bring private benefit such as good reputation and honor to insiders, Reference ${ }^{19}$ suggested that there was a tendency that as the percentage of shareholding was higher, they increased the expense of CSR activity more, and as the percentage was lower, they decreased the expense more. The study in Reference ${ }^{20}$ argues that consideration for interested parties through the fulfillment of social responsibility plays a positive role and shareholders' interest can correspond to interested parties' interest. The study in Reference ${ }^{21}$ observes that foreign investors' investment has a strong tendency of long-term investment and that plays a role of a factor to increase external CSR activity to increase the corporate value, which is the major concern of shareholders. Therefore, as the governance structure system is sounder, according to many viewpoints, the system would affect the corporate administration to control better the influence that CSR has on the corporate performance, and it is assumable that the effort to actively and strategically utilize CSR activity would be stronger.

Based on the above, the following hypothesis was set.

Hypothesis 2: The governance structure would moderate the relationship between CSR and the corporate performance.

\section{Proposed Method}

\subsection{Research Model}

To figure out if the corporate governance structure affects the corporate performance through CSR, this paper set the governance structure propriety factor as independent variable, the social responsibility as mediating variable, and the corporate performance as dependent variable. The research model to achieve the objective of this study is follows (Figure 1).

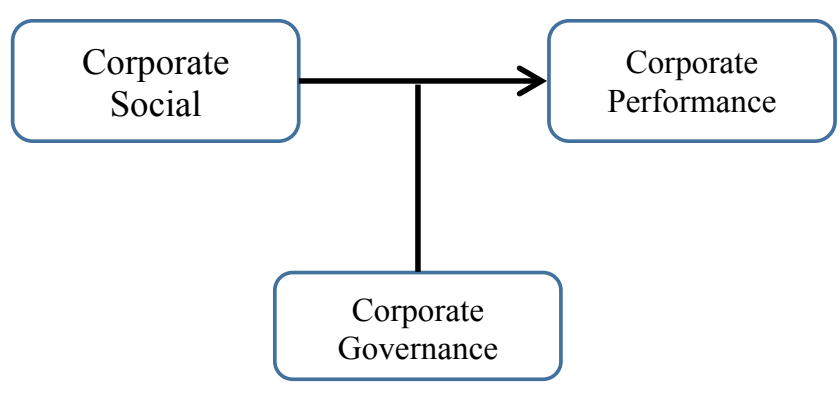

Figure 1. Research model.

\subsection{Variable Definition}

\subsubsection{Social Responsibility}

Social Responsibility index is KEJI index based on KEJI awards database that measured scores by separating soundness, fairness, social volunteer contribution, environmental protection satisfaction, consumer protection contribution, employee satisfaction, economic development contribution, and the total score was used to analyze.

\subsubsection{Governance Structure}

The corporate governance structure appraisal used date written by KCGIS targeting public corporations 
based on the model norms of the corporate governance structure. In other words, it used listed corporations' governance structure as the substitute of the corporate governance in the year. The departmental corporate governance structure that consists of whole of the corporate governance structures of KCGIS is divided into shareholder right protection, organization and operation of the board, posting, audit, negligence distribution, and each of departmental governance index forms the whole corporate governance index and the rate is determined with the index.

\subsubsection{Corporate Performance}

The corporate performance used ROA as the substitute. The corporate performance is the financial ratio to measure the degree of how the executives efficiently used the assets to make a profit. In this case, it measured business profits divided by assets to measure the efficiency of the business.

\subsubsection{Control Variable}

As control variables, it included the number of employees, business scale: the natural log of assets, debt rate, and $R \& D$ expense. When looking at existing studies, the scale of assets has a positive relationship with the corporate performance, and accordingly it turns out that as the scale of assets was bigger, the corporate performance was higher ${ }^{4,22,23}$. And debt rate and the corporate performance showed significant negative relationship. In other words, it implies that as the debt rate is higher, the net profit during the term is lower due to the interest burden ${ }^{24,25}$. Besides, R\&D expense from sales revealing business growth, had a significant relationship with the corporate performance ${ }^{4}$.

\subsection{Sample Selection}

In order to find out what relations the governance structure has between CSR and the corporate performance, this study examined and collected data targeting corporations of which the governance structure rate and social responsibility index were measured for 6 years from 2008 to 2013. For pragmatic analysis, however, the data for 4 years from 2010 to 2013 were utilized which contained the governance structure rate, social responsibility index, and the corporate performance altogether.

\section{Experimental Results}

\subsection{Descriptive Statistics}

In order to find out what relations the governance structure has between CSR and the corporate performance, the paper analyzed targeted corporations of which the governance structure rate and social responsibility index, KEJI index, were measured for 6 years from 2008 to 2013. For empirical analysis, it referred to the data of Corporate Governance Service Center as the corporate governance data, and the KEJI index of Citizens' Coalition for Economic Justice Institute as the social responsibility data. As for the corporate performance, ROA evaluation of the corporation was used for analysis.

Table 1 shows the results of a descriptive statistics for corporate performance.

Taking a look on the descriptive statistics of variables; the average of the corporate performance was 1.1213; the minimum value was 0.16 ; the maximum was 4.13 . As for control variables, the average of total assets was 2,573 billion won; the minimum was 52 billion won; the maximum was 86,024 billion won. The average of debt rate was $79.27 \%$ and the maximum was $412.58 \%$. The average of R\&D expense from sales was 0.0012 , which presented that about $0.12 \%$ of assets was invested to R\&D.

\subsection{Hypothesis Verification}

Moderator regression analysis was conducted to verify the moderating effect of the governance structure between CSR and the corporate performance. The analysis method in the 1st step had control variables such as debt rate, the number of employees, log assets, $R \& D$ expense from sales regarding the corporate performance. In the 2nd step, CSR, the independent variable was added; In the $3 \mathrm{rd}$ step, the governance structure, the moderating variable, was put; In the 4th step, the interactive term of the independent variable and moderating variable was put. The verification of moderating effect presented statistically significant moderating effect after comparing $\mathrm{R}^{2}$ of the regression equation in the 3 rd step where the independent variable and moderating variable were put simultaneously with increased $\mathrm{R}^{2}\left(\Delta \mathrm{R}^{2}\right)$ in the 4 th step where the interactive term of the independent variable and moderating variable was put additionally. The results of the statistical analysis as shown in Table 2, the contents of which are as follows. 
Table 1. Summary of descriptive statistics

\begin{tabular}{|c|c|c|c|c|c|c|}
\hline & $\mathrm{N}$ & M & SD & Min & Max & Reference \\
\hline CGI & 178 & 3.4972 & .75 & 3.00 & 6.00 & CGI: Corporate Governance Index \\
\hline ROA & 178 & 1.1213 & .50 & .16 & 4.13 & $\begin{array}{l}\text { the corporate performance: Operating } \\
\text { profit/Total assets }\end{array}$ \\
\hline CSR & 178 & 3.9354 & 2.07 & 1.00 & 7.00 & $\begin{array}{l}\text { CSR: Corporate Social Responsibility } \\
\text { index }\end{array}$ \\
\hline IND & 178 & 1.2416 & .43 & 1.00 & 2.00 & IND: Industry dummy \\
\hline ASSET & 178 & $2,573,464$ & $8,210,863$ & 52,405 & $86,024,154$ & ASSET: Total asset(unit; million won) \\
\hline SIZE & 178 & 8.7668 & .64 & 7.72 & 10.93 & SIZE: LG(Assets) \\
\hline EQUITY & 178 & $126,400,479$ & $296,781,183$ & $5,207,500$ & $2,315,654,175$ & $\begin{array}{l}\text { EQUITY: Total equity amount(unit; } \\
\text { million won) }\end{array}$ \\
\hline LEV & 178 & 79.2739 & 63.60 & 10.82 & 412.58 & LEV: Debt/equity ratio(\%) \\
\hline SALES & 178 & 617,301 & $1,810,800$ & 45,652 & $23,157,822$ & SALES: Sales(unit; million won) \\
\hline OPRINC & 178 & $2,386,225$ & $8,104,122$ & 50,224 & $89,772,834$ & $\begin{array}{l}\text { OPRINC: Operating profit (unit; million } \\
\text { won) }\end{array}$ \\
\hline NETINC & 178 & 153,206 & 889,784 & $(4,719,632,924)$ & $9,649,487$ & NETINC: Net profit (unit; million won) \\
\hline $\mathrm{R} \& \mathrm{D}$ & 178 & 736,768 & $1,277,745$ & 0 & $9,244,110$ & R\&D: R\&D expense(unit; million won) \\
\hline $\begin{array}{l}\text { R\&D/ } \\
\text { SALES }\end{array}$ & 178 & .0012 & .80 & .00 & 8.39 & R\&D/SALES: R\&D expense/sales \\
\hline
\end{tabular}

Table 2. Moderating effect of governance structure between CSR and performance

\begin{tabular}{|c|c|c|c|c|c|c|c|c|}
\hline \multirow{3}{*}{ variable } & \multicolumn{8}{|c|}{ the corporate performance } \\
\hline & \multicolumn{2}{|c|}{ model1 } & \multicolumn{2}{|c|}{ mode 2} & \multicolumn{2}{|c|}{ mode3 } & \multicolumn{2}{|c|}{ mode 4} \\
\hline & B & $\mathrm{t}$ & B & $\mathrm{t}$ & B & $t$ & B & $\mathrm{t}$ \\
\hline constant & 1.267 & 7.810 & 1.168 & 7.454 & 1.301 & 8.300 & 1.501 & 8.483 \\
\hline LEV & -.001 & -6.800 & -.001 & -4.695 & -.001 & -4.514 & -.001 & -4.631 \\
\hline EMP & .000 & .498 & .000 & -1.523 & .000 & -2.602 & .000 & -3.365 \\
\hline SIZE & -.007 & -.361 & -.027 & -1.439 & -.080 & -3.949 & -.076 & -3.768 \\
\hline R\&D SALES & .015 & 1.268 & -.002 & -.181 & -.009 & -.756 & -.013 & -1.116 \\
\hline CSR & & & .065 & $14.440^{* *}$ & .061 & $13.671^{\star *}$ & .008 & .379 \\
\hline CGI & & & & & .099 & $6.749^{\star *}$ & .032 & 1.047 \\
\hline CSR X CGI & & & & & & & .015 & $2.428^{\star}$ \\
\hline $\mathrm{F}$ & \multicolumn{2}{|c|}{$15.135^{\star *}$} & \multicolumn{2}{|c|}{$54.695^{\star *}$} & \multicolumn{2}{|c|}{$53.885^{\star *}$} & \multicolumn{2}{|c|}{$47.109^{* *}$} \\
\hline MSE & \multicolumn{2}{|c|}{.243} & \multicolumn{2}{|c|}{.226} & \multicolumn{2}{|c|}{.223} & \multicolumn{2}{|c|}{.222} \\
\hline $\mathrm{R}^{2}$ & \multicolumn{2}{|c|}{.021} & \multicolumn{2}{|c|}{.088} & \multicolumn{2}{|c|}{.102} & \multicolumn{2}{|c|}{.104} \\
\hline$\Delta \mathrm{R}^{2}$ & & & \multicolumn{2}{|c|}{.067} & \multicolumn{2}{|c|}{.014} & \multicolumn{2}{|c|}{.002} \\
\hline
\end{tabular}

${ }^{*} \mathrm{p}<0,05,{ }^{* *} \mathrm{p}<0.01$. 
First, the verification result of Hypothesis 1 (Table 2-model 2), presented that CSR had positive effect on the corporate performance $(\beta=.065, \mathrm{t}=14.440, \mathrm{p}<0.01)$. As seen from $\mathrm{R}^{2}=.088$, the corporate performance ratio explained by CSR is .088. The value of $\mathrm{F}$ is measured as 54.695 and estimated p-value of regression analysis model turned out to be $\mathrm{p}<0.01$, which implied the overall significance of the regression analysis model was high. Therefore, Hypothesis 1 that CSR would affect the corporate performance has been adopted. These results that coincide with the precedent studies ${ }^{4,7,11,12}$ indicate that corporations are able to improve the performance by increasing CSR activities.

Second, in order to verify hypothesis 2 , the moderating effect was analyzed by putting the governance structure into model 3, the interactive term that is CSR X CGI between CSR and CGI into model 4. The analysis result of the governance structure indicated that the governance structure had a significant positive effect on the corporate performance $(\beta=.099, \mathrm{t}=6.749, \mathrm{p}<0.01)$ as seen in Table 2-model 3. In addition, CSR X CGI ( $\beta=.015$, $\mathrm{t}=2.428, \mathrm{p}<0.05)$, the interactive term of CSR and CGI, had a significant effect on the corporate performance (Table 2-model 4 ). The value of $\mathrm{R}^{2}$ increased by the addition of the interactive term of the independent variable and moderating variable after putting the control variable, independent variable, moderating variable into the corporate performance was $104(\mathrm{p}<0.05)$, which showed a significant increase. Thus, Hypothesis 2 has been adopted.

These results imply that the sounder the governance structure is, the better influence CSR has on the performance.

\section{Conclusion}

As the global economy has constantly developed, the implementation of CSR has emerged as an important issue. Therefore, this study analyzed how CSR affects corporations, and furthermore, how differently CSR affects the corporate performance depending on the governance structure.

As the result of empirical analysis, first, CSR turns out to have a positive effect on the performance, and the result suggests that there are inducements for corporations to voluntarily and consistently implement CSR activities. Second, there is the moderating effect of the governance structure between CSR and the performance.
Considering that agency costs would be incurred by the conflict between shareholders and executives when making a decision and proceeding to do CSR activity, that the effect that CSR has on the performance varies based on the governance structure implies that having the governance structure sound improves the corporate performance.

This paper among other studies on CSR has significance in that it analyzed the moderating effect of corporate governance structure between CSR and the corporate performance for the first time. Moreover, regarding the implementation of CSR activity and improvement of the corporate performance, this paper presented the direction on how to manipulate the governance structure so that it can establish a better structure and improve the effect of CSR activities, which adds importance in this paper.

Above all, the inducements to implement CSR activities voluntarily and consistently were found. The significant result of this study is also practically meaningful and able to present a direction for policy making of the government on the corporate social responsibility.

Nevertheless, there is a limit of the expediency of sample selection since the research period was relatively short and the samples were made up of given CSR scores from the public corporations, although this approached to 4 years of panel data regarding the relationship between CSR and the corporate value. Therefore, the tasks to be done in the future include a relevant study consists of a considerable number of samples and time series data covering long period.

\section{References}

1. Barnea A, Rubin A. Corporate social responsibility as a conflict between shareholders. Journal of Business Ethics. 2010; 97(1):71-86.

2. Hammond SA, Slocum JWJ. The impact of prior firm financial performance on subsequent corporate reputation. Journal of Business Ethics. 1996; 15(2):159-65.

3. Brammer S, Brooks C, Pavelin S. Corporate social performance and stock returns: UK evidence from disaggregate measures. Working Paper; 2005.

4. Park H, Kang D, Kwon I, Shin H. Corporate transparency and its value. Korean Management Review. 2006; 35(5):1361-91.

5. Bowen H. Social responsibilities of the businessman. Haper and Row: New York; 1953.

6. ShinYG. Socially responsible management: business and society. KyungMoonSa; 2001. 
7. HeoI G. Corporate social responsibility and competitive advantage of Korean Companies. Doctoral Dissertation. Pusan National University; 2008.

8. Pava M, Krausz J. The association between corporate social responsibility and financial performance: The paradox of social cost. Journal of Business Ethics. 1996; 15:321-57.

9. Hillman, AJ, Keim GD. Shareholder value, stakeholder management, and social issues: What's the bottom line. Strategic Management Journal. 2001; 22:125-39.

10. Clarkson MBE. A stakeholder framework for analyzing and evaluating corporate social performance. Academy of Management Review. 1995; 20(1):92-117.

11. Waddock SA, Graves SB. The corporate social performancefinancial performance link. Strategic Management Journal. 1997; 18(4):303-19.

12. Orlitzky M, Schmidt F, Rynes S. Corporate social and financial performance: A meta-analysis. Organization Studies. 2003; 24:408-441.

13. Hwang BI. The effects of corporate expertise, trustworthiness, social responsibility on corporate reputation and customer's relationship retention intention. The Korean Journal of Advertising. 2004; 15(5):361-78.

14. Griffin JJ, Mahon JF. The corporate social performance and corporate financial performance debate: Twenty-five tears of incomparable research. business and society. 1997; 36:5-31.

15. McWilliams A, Siegel D. Corporate social responsibility and financial performance: Correlation or misspecification? Strategic Management Journal. 2000; 21:603-9.

16. Nelling E, Webb E. Corporate social responsibility and financial performance: The "virtuous circle? Revisited.
Review of Quantitative Finance and Accounting. 2009; 32(2):197-209.

17. Johnson JL, Daily CM, Ellstradn AE. Boards of directors: A review and research agenda. Journal of Management. 1996; 22:409-30.

18. Zahra S, Pearce J. Boards of directors and corporate financial performance: A review and integrative model. Journal of Management. 1989; 15:14-159.

19. Barnea A, Rubin A. Corporate social responsibility as a conflict between shareholders. Working Paper; 2006.

20. Aguilera RV, Williams C, Conley JM, Rupp D. Corporate governance and corporate social responsibility. A Comparative Analysis of the U.K. and the U.S. Corporate Governance. An International Review. 2006; 14(3):147-58.

21. Park KS, Lee EJ. The role of foreign investors on the management and corporate governance of Korean companies. Journal of Money and Finance. 2006; 20(2):129-55.

22. Joh SW. Corporate governance and firm profitability: Evidence from Korea before the economic crisis. Working paper. KDI; 2001.

23. Krivogorsky V. Ownership, board structure, and performance in continental Europe. The International Journal of Accounting. 2006; 41:176-97.

24. Yi HJ, Moon SH. The effect of corporate governance on the quality of earnings, operating performance, and firm value. Korean Accounting Association Conference; 2005.

25. Yoon BH, Oh JY. Korean case studies on corporate governance and firm's performance, Value and Market Returns. Asia-Pacific Journal of Financial Studies. 2005; 34(1): 227-63. 